\title{
The Bell that Rings Light
}

A Primer in Quantum Mechanics and Chemical Bonding 


\section{Mathematics Across the Curriculum}

Series Editor: Dorothy Wallace (Dartmouth College, USA)

ISSN: $1793-3145$

\section{Vol. 1: The Bell that Rings Light}

A Primer in Quantum Mechanics and Chemical Bonding by Dorothy Wallace and Joseph J. BelBruno 
Mathematics Across the Curriculum - Vol.1

\section{The Bell that Rings light}

A Primer in Quantum Mechanics and Chemical Bonding

\section{Dorothy Wallace \& Joseph J BelBruno}

Dartmouth College, USA 


\section{Published by}

World Scientific Publishing Co. Pte. Ltd.

5 Toh Tuck Link, Singapore 596224

USA office: 27 Warren Street, Suite 401-402, Hackensack, NJ 07601

UK office: 57 Shelton Street, Covent Garden, London WC2H 9HE

\section{British Library Cataloguing-in-Publication Data}

A catalogue record for this book is available from the British Library.

\section{Mathematics Across the Curriculum - Vol. 1}

\section{THE BELL THAT RINGS LIGHT}

\section{A Primer in Quantum Mechanies and Chemical Bonding}

\section{Copyright $\odot 2006$ by World Scientific Publishing Co. Pte. Ltd.}

All rights reserved. This book, or parts thereof, may not be reproduced in any form or by any means, electronic or mechanical, including photocopying, recording or any information storage and retrieval system now known or to be invented, without written permission from the Publisher.

For photocopying of material in this volume, please pay a copying fee through the Copyright Clearance Center, Inc., 222 Rosewood Drive, Danvers, MA 01923, USA. In this case permission to photocopy is not required from the publisher.

ISBN 981-256-705-4

ISBN $981-256-706-2$ (pbk)

Typeset by Stallion Press

Email: enquiries@stallionpress.com 
To Kathy, Joe and Lizzy:

Your love and enthusiasm

provide the encouragement

for my many projects.

J.J. BelBruno

To Maria:

Love and sweet reason toss

this rose at your feet.

Read it some day.

D.I. Wallace 
This page is intentionally left blank 


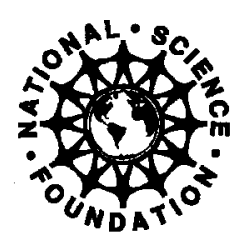

\title{
Acknowledgement
}

\begin{abstract}
The authors wish to thank the National Science Foundation (NSF) for its generous support for this project and many others through the 'Dartmouth Mathematics Across the Curriculum Project', DUE-9552462. NSF, an independent agency of the U.S. government, funds research in science and education.
\end{abstract}


This page is intentionally left blank 


\section{Preface}

Once upon a time I wanted to be a chemist. I guess almost everybody goes through a lot of different imaginings during childhood, and I suppose society has a right to worry about some of them. But if you are like I was, a fair amount of your energy goes into imagining how you might someday make your living, and whether or not you will ever find something you can truly call your vocation.

Now, vocation is not just some three syllable word for "job". It has connotations of what the clergy name a "calling", as in, "Have you felt called to the service of the Lord?" A lucky few people hear such a calling, although most hear faint siren voices, luring them toward ends that neither compel nor provide a living. You can hear these voices too, just practice your favorite hobby or sport for several days in a row and see if you can't hear a whisper or two telling you to make this your passion and livelihood. Well, anyway, all this is to say that once when I was still in high school I thought maybe chemistry was calling me in this way.

We had just finished studying some fairly difficult stuff, I no longer remember what. I was feeling on top of the material and for no real reason sought out the science section of the town library. In it, I found two books, both entitled "The Hydrogen Atom". If you are reading this story, you are likely to know that the hydrogen atom is lesson number one for high school chemistry students. No atom is simpler, just one little proton and one even littler electron account for everything the little guy does. And here, right in front of me, are two books on just this one atom, the first one truly huge, as big as our whole chemistry textbook, and the second one about half that size. I took the small one, under the very mistaken impression that small equals simple, and sat down for a while to read. The first very noticeable thing about this book was the absence of the following picture: 


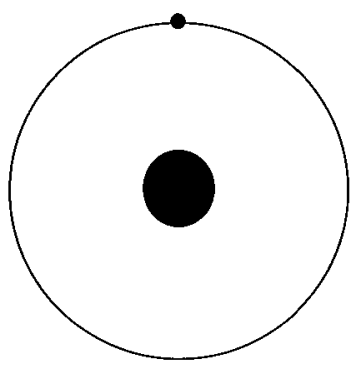

You must know that this picture is required, by law, to precede every discussion of the hydrogen atom. And the discussion always starts, "Now, this (pointing) is a proton and this is an electron, and the little one goes around the big one, just as Rutherford figured out in 210 B.C. and this is the gospel truth!" Now, may be you can't tell that I am trying to make sport of science textbooks, so here I let you in on my little secret. The minute anybody tries to tell you that some scientific explanation for something is the truth, you have to know you are in the presence of someone who has written, is writing, or is about to write a textbook. At the moment in my life when I opened that book on the hydrogen atom in the San Mateo public library, textbooks were all I had ever seen. And this new book did not resemble any of them. It had no pictures of genteel electrons orbiting politely stationary nuclei, it made no mention of Rutherford or Bohr; it made no reference to anything in my familiar old chemistry textbook. The sole intersection of that book and my understanding lay in the use of the word "hydrogen" and the ubiquitous display of derivatives of various functions, everywhere, standing in bizarre relationships to one another. In fact, the little book on the hydrogen atom seemed to be exactly the same as the big book on the hydrogen atom, except that all of the words had been removed.

Some time later that same year I found out that I had been in the presence of quantum mechanics, a way to look at small-scale phenomena in terms of quantities that they possess, such as energy, momentum, location. These functions describing the object stand in for the actual object itself, and all relationships among objects are newly expressed by relationships between the functions that describe them. I will dwell more on this later, I only mention it now to explain the presence of all those derivatives and equations that made up most of the text of the book I was holding in my hands. 
Well, physics is not my vocation and neither is chemistry, although the mysterious book on the hydrogen atom did motivate me to enroll in and then drop out of a college quantum mechanics course. I enrolled in it to understand the book I had found and I dropped out of it because it began, more or less, with "this is Schrödinger's equation", providing none of the connection I sought between Mr. Schrödinger and poor old Rutherford and Bohr. Meanwhile, I became a mathematician. And because of that little book, for the last twenty years I have made it my hobby to piece together the story of the hydrogen atom, how it grew from a simple little sun-plusplanet into the set of equations that Schrodinger gave, and how the solution to those equations answers questions posed by Bohr himself.

This little book is my gift to myself. It is the book I wish I had found next to those two others when I went to the library, so that I could have reached, with my still limited knowledge of physics and mathematics, the place where the other books began. This book is for you, too, especially if you are taking a physics or chemistry course now. In it, you will find some glue to help patch up your picture of the universe, especially the very small things in it. 
This page is intentionally left blank 


\section{Contents}

$\begin{array}{lll}\text { Preface } & \text { ix }\end{array}$

$\begin{array}{lll}\text { Chapter } 1 & \text { Rutherford, Bohr and Balmer } & 1\end{array}$

$\begin{array}{lll}\text { Chapter } 2 & \text { Some Important Experiments } & 7\end{array}$

Chapter 3 Early Quantum Mechanics: The Atom 15

$\begin{array}{lll}\text { Chapter } 4 \text { New Assumptions } & 19\end{array}$

Chapter 5 Zetetics 23

Chapter 6 Classical Waves 31

$\begin{array}{lll}\text { Chapter } 7 & \text { Particle-in-a-Box } & 39\end{array}$

Chapter 8 Exploring the Analogy 45

Chapter 9 Dr. Schrödinger, I Presume? 49

Chapter 10 The Quantum Numbers 53

Chapter 11 Pleased to Meet you, Dr. Schur 59

Chapter 12 The Spherical Harmonics 65

$\begin{array}{lll}\text { Chapter } 13 \text { More French Mathematicians } & 71\end{array}$

$\begin{array}{lll}\text { Chapter } 14 & \text { Reprise: The Quantum Numbers } & 77\end{array}$

$\begin{array}{lll}\text { Chapter } 15 & \text { Chemistry and Bonding } & 81\end{array}$ 
xiv The Bell That Rings Light

Chapter $16 \quad$ Valence Shell Electron Pair Repulsion 89

$\begin{array}{lll}\text { Chapter } 17 & \text { The Shape of an Orbital } & 93\end{array}$

$\begin{array}{lll}\text { Chapter } 18 & \text { Molecular Orbital Theory }\end{array}$

$\begin{array}{lll}\text { Chapter } 19 & \text { Valence Bond Theory } & 117\end{array}$

$\begin{array}{lll}\text { Chapter } 20 & \text { Other Kinds of Bonding } & 123\end{array}$

$\begin{array}{lll}\text { Chapter } 21 & \text { Case Study: Dye Molecules } & 129\end{array}$

$\begin{array}{lll}\text { Chapter 22 } & \text { Afterword }\end{array}$

$\begin{array}{ll}\text { Index } & 137\end{array}$ 